\title{
Perceptions of point-of-care infectious disease testing among European medical personnel, point-of-care test kit manufacturers, and the general public
}

\author{
This article was published in the following Dove Press journal: \\ Patient Preference and Adherence \\ 18 June 2013 \\ Number of times this article has been viewed
}

\author{
Wendy E Kaman' \\ Eleni-Rosalina \\ Andrinopoulou ${ }^{2}$ \\ John P Hays' \\ 'Department of Medical Microbiology \\ and Infectious Diseases, Erasmus \\ Medical Center, Rotterdam, The \\ Netherlands; ${ }^{2}$ Department of \\ Biostatistics, Erasmus Medical \\ Center, Rotterdam, The Netherlands
}

\begin{abstract}
Background: The proper development and implementation of point-of-care (POC) diagnostics requires knowledge of the perceived requirements and barriers to their implementation. To determine the current requirements and perceived barriers to the introduction of POC diagnostics in the field of medical microbiology (MM)-POC a prospective online survey (TEMPOtest-QC) was established.
\end{abstract}

Methods and results: The TEMPOtest-QC survey was online between February 2011 and July 2012 and targeted the medical community, POC test diagnostic manufacturers, general practitioners, and the general public. In total, 293 individuals responded to the survey, including 91 (31\%) medical microbiologists, 39 (13\%) nonmedical microbiologists, 25 (9\%) employees of POC test manufacturers, and $138(47 \%)$ members of the general public. Responses were received from 18 different European countries, with the largest percentage of these living in The Netherlands (52\%). The majority ( $>50 \%$ ) of medical specialists regarded the development of MM-POC for blood culture and hospital acquired infections as "absolutely necessary", but were much less favorable towards their use in the home environment. Significant differences in perceptions between medical specialists and the general public included the: (1) Effect on quality of patient care; (2) Ability to better monitor patients; (3) Home testing and the doctor-patient relationship; and (4) MM-POC interpretation. Only 34.7\% of the general public is willing to pay more than $€ 10(\$ 13)$ for a single MM-POC test, with $85.5 \%$ preferring to purchase their MM-POC test from a pharmacy.

Conclusion: The requirements for the proper implementation of MM-POC were found to be generally similar between medical specialists and POC test kit manufacturers. The general public was much more favorable with respect to a perceived improvement in the quality of healthcare that these tests would bring to the hospital and home environment.

Keywords: Survey, questionnaire, point-of-care, microbial diagnosis

\section{Introduction}

Progress in the field of rapid and point-of-care (POC) diagnostics has been relatively slow, especially with respect to medical microbiology (MM) and the diagnosis of infectious diseases. ${ }^{1}$ In particular, the culture of microorganisms such as bacteria and fungi on solid or liquid growth medium still remains the "gold standard" by which POC diagnostic tests in MM (MM-POC) are compared. ${ }^{2}$ However, the identification of pathogens by culture, as well as the confirmation of their antimicrobial sensitivity profiles, are time consuming and require the skills of dedicated and trained medical
Department of Medical Microbiology and Infectious Diseases, Erasmus Medical Center, Gravendijkwal 230, 3015 CE Rotterdam, The Netherlands

$\mathrm{Tel}+31107032177$

$\mathrm{Fax}+31107033875$

Email j.hays@erasmusmc.nl 
laboratory personnel. Surrogate markers of infection are becoming available as rapid diagnostics for the determination of the presence or absence of an infection, including the measurement of $\mathrm{C}$ reactive protein and procalcitonin. Moreover, there is evidence to suggest that these surrogate markers may be useful in the detection of an infection in seriously ill patients in the nosocomial environment. ${ }^{3-6}$ Additionally, specific molecular and antibody based diagnostic methods are becoming more readily available in many medical disciplines, including virology, emergency medicine, etc. ${ }^{7,8}$ However, POC test (POCT) manufacturers have generally been slow in developing POC devices for the detection of infectious diseases, particularly for infections caused by bacterial and fungal pathogens, even though the development of such diagnostic devices would facilitate the rapid identification of these infectious agents (if present) and allow better targeted prescribing of suitable antimicrobial therapy. ${ }^{8}$ Further, the largest trend in the field of rapid microbiological diagnostics currently involves the evaluation and validation of new technologies within the medical microbiology laboratory per se, particularly the evaluation and validation of nucleic acid amplification technologies and mass spectrophotometric methods. This means that there still remains a large untapped market for the introduction of POC microbiological diagnostics for such target audiences as professional nonmicrobiologist medical professionals, general practitioners and even patients (within their own homes). The use of POC devices by the above mentioned target groups would provide tangible benefits for all concerned, including more accurate, rapid, and cheaper diagnosis of microbiological infections, whilst providing accompanying advantages with respect to national healthcare budgets; eg, by facilitating earlier discharge from hospital and helping reduce the use of staff and equipment, ${ }^{9-11}$ and for example by shifting the burden of healthcare from healthcare providers to the actual patients themselves. Further, such market developments could provide significant advances with respect to limiting the ever growing threat of antimicrobial resistance and its impact on patient morbidity and mortality. ${ }^{12,13}$ In fact, the administration of suitable antibiotic therapy in the early onset of an infectious disease has been shown to improve the outcome of critically ill patients, with guidelines being available for the prescription of empirical antimicrobial therapy; ie, the prescribing of antimicrobial therapy before culture results become available. ${ }^{14}$ Moreover, the inappropriate use of antibiotics is closely linked to the development of antibiotic resistant microorganisms, ${ }^{15}$ and importantly, antibiotics are ineffective when used to treat viral infections. Further, the global increasing prevalence of antimicrobial resistance has not gone unnoticed by regulatory bodies such as the National Institute of Health and the World Health Organization.

The European Union is also facing up to its responsibilities with respect to infectious disease diagnosis and the provision of improved healthcare to European citizens, having funded several projects that have investigated the development and potential of rapid and POC infectious disease diagnostics. In particular, the "TEMPOtest-QC" project (www. TEMPOtest-QC.eu) was designed to help "fill the current gap between microbiological POC testing technologies and actual clinical need", and provide a "toolkit" (biobank of specimens, bacterial isolates, facilities and expertise, etc $)^{16}$ to help small and medium-sized enterprises (SME) evaluate and validate new technologies during the development of MM-POC diagnostics. In this respect, one of the main tasks of the project was to help stakeholders (medical professionals, general practitioners, developers and manufacturers, and the general public) understand the perceptions and requirements for MM-POC diagnostics within hospital, general surgery, and home environments. In turn, the knowledge from this study will help the stakeholders to better understand the requirements and potential hurdles to the introduction of MM-POC devices into healthcare environments, ${ }^{17,18}$ be it the hospital laboratory, by the bedside, at the general practitioner's surgery, or even within the patient's own home.

\section{Methods}

\section{Survey}

As part of the TEMPOtest-QC project goals, an online survey was established in order to determine the views and perceived requirements of European citizens to infectious disease (bacterial/fungal) MM-POC testing (Supplemental Data Appendix S1). For some questions multiple answers were allowed, which means that for some questions the number of responses may be greater than the number of respondents. Target groups for the survey were: (1) hospital medical microbiologists, including medical microbiology laboratory technicians; (2) nonmedical microbiology specialists (hospital doctors and nurses); (3) POC test manufacturers (employees of POC test manufacturers); (4) the general public; and (5) general practitioners. The questionnaire remained open for online respondents from 08/16/2011 to 06/22/2012; a total of 10 months. These target groups were approached using: (1) an online website (www.tempotest-qc.eu); (2) a press release ("Join the fight against resistant bacteria!" by AlphaGalileo Foundation); (3) online social media, including YouTube (http://www.youtube. com/watch? $\mathrm{v}=\mathrm{t} 1 \mathrm{Ni}$ VtnFuI), and relevant discussion groups 
on Linked-In (www.linkedin.com); (4) an advertisement in a national Dutch free newspaper (Metro); (5) an advertisement in a local internal hospital newspaper (Ziekenhuiskrant); as well as (6) flyers and poster presentations at multiple European scientific conferences (Figure 1). The online and voluntary nature of the survey meant that we were unable to record the number of nonresponders. Moreover, the survey was designed so that all questions in the questionnaire had to be completed before the opinions of respondents could be successfully submitted.

\section{Statistical analysis}

The association between the categorical variables (answer and group) was assessed using the Chi-square test or Fisher's exact test when appropriate. Univariate logistic regression and odds ratio (OR) with 95\% confidence intervals were calculated and used to compare the opinions of medical specialists and POCT manufacturers and the general public. Two sided $P$-values of $<0.05$ were considered significant. All analyses were performed using the statistical software package R (free download from http://www.R-project.org/) version 2.15.1 (The R Foundation for Statistical Computing, Vienna, Austria). ${ }^{19}$ In order to increase the sample size for statistical analysis, the survey results of the hospital medical microbiologists target group $(n=91)$ were merged with the answers of the nonmicrobiology specialists $(n=39)$ and the combined group $(n=130)$ was referred to as "medical specialists".

\section{Ethical statement}

This study did not involve categorizing humans by race/ethnicity, age, disease/disabilities, religion, sex/ gender, sexual orientation, or other socially constructed groupings. All results were collected anonymously using an online questionnaire which was available at www.TEMPOtest-QC.eu. The questionnaire asked volunteer respondents to provide their opinions on the development and potential hurdles to MM-POC testing. Although data was collected on country of employment, country of birth, and occupation, country of employment data was utilized to provide an indication of how successful the questionnaire "promotional campaign" was, and country of birth data was used to provide an indication of the geographical diversity of the respondent's opinions. Both country of birth and country of employ-

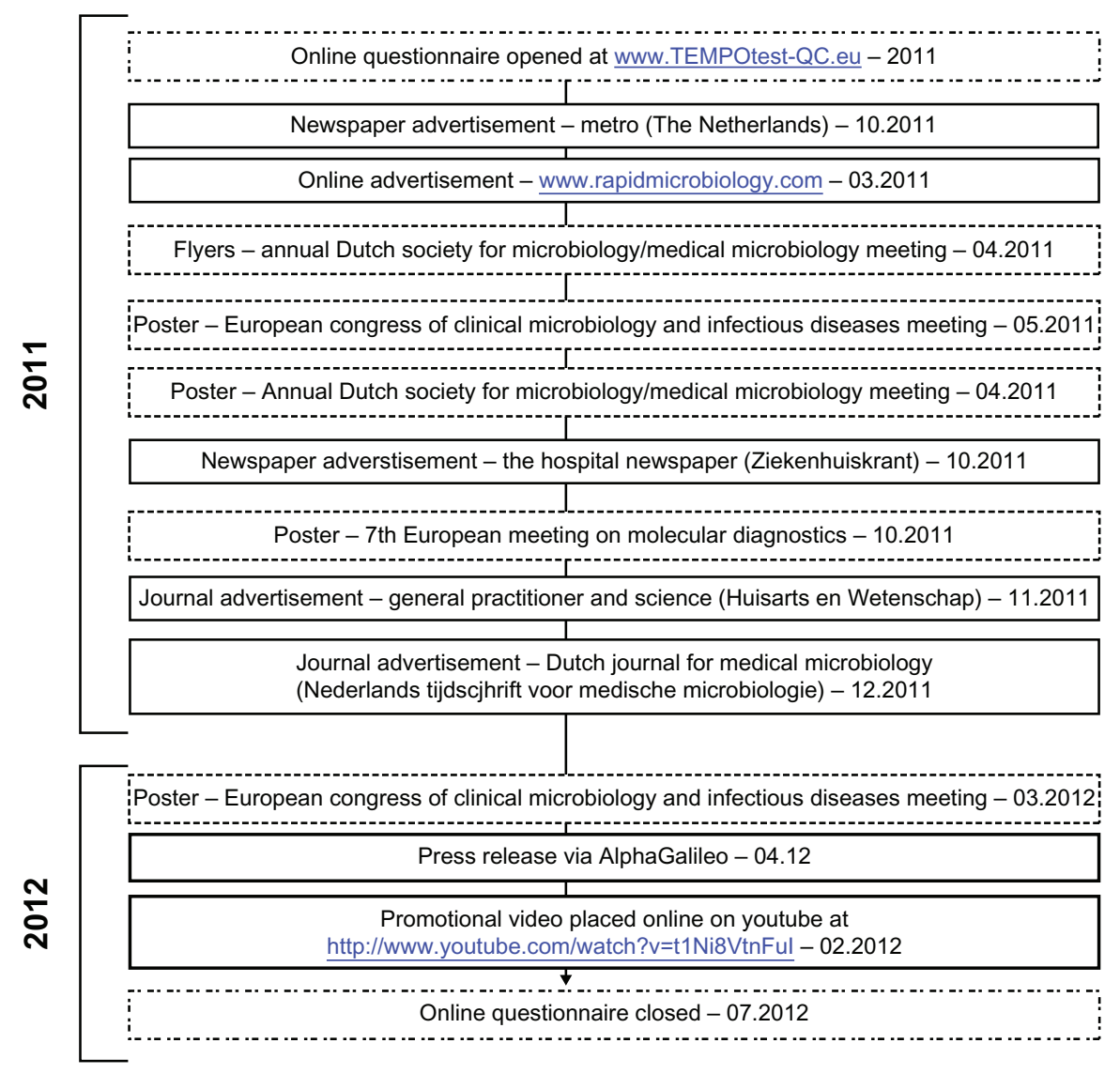

Figure I Table showing the timeline and activities associated with the dissemination of the TEMPOtest-QC questionnaire. 
ment data were not used in subsequent statistical analyses of the results. Full details regarding the TEMPOtest-QC study protocol and objectives of the study were available online on the same webpage as the link to the questionnaire, and there was no compulsion for interested parties to participate in the questionnaire. For all of these reasons ethical approval for the study was not requested from the host institution (Erasmus Medical Center, Rotterdam, The Netherlands).

\section{Results}

\section{Respondent characteristics}

Overall, 293 individuals responded to the survey within the 10 months that the questionnaire was available online, with 91 (31\%) participants responding as medical specialist (medical microbiologists), 39 (13\%) as medical specialist (nonmedical microbiologists), 25 (9\%) as employees of POC test manufacturers and $138(47 \%)$ responding as members of the general public (Figure 2A). The largest percentage of these participants were born and living in The Netherlands, though responses were also received from respondents born or living in Poland, Italy, the United Kingdom, Belgium, and France among others (Figure 2B and C). In total, responses were received from respondents born and/or currently working in 18 different European countries. Responses were also received from eleven general practitioners practicing in The Netherlands. However, these results have been omitted due to the low numbers of respondents in this target group. Of the medical microbiologist respondents, $24 \%$ reported to occasionally use a POC diagnostic device for the diagnosis of infectious diseases. The majority (68\%) of medical microbiological pointof-care test (MM-POC) devices currently used were based on antibody related detection technologies.

\section{POC infectious disease diagnostics and their specifications}

As previously mentioned, the availability of POC diagnostics for (bacterial/fungal) infectious disease testing currently lags behind the availability of POC diagnostics in other fields of medicine, such as clinical chemistry and virology. Therefore, one of the first questions asked of the medical specialist (medical microbiologists and nonmicrobiologists) target groups was designed to obtain their opinions on how important an infectious disease (bacterial/ fungal) POC diagnostic device would be in helping diagnose various infectious disease-related conditions. The majority of respondents considered MM-POC devices most useful in the diagnosis of blood culture infections, followed by hospital acquired infections and respiratory infections (Figure 3). There was less enthusiasm for the detection of oral and urinary tract infections. Interestingly, when asked for their opinions on the use of such MM-POC devices within various medical environments, there was a generally favorable response of medical specialists, POCT developers, and the general public for the use of MM-POC diagnostics in the hospital ward and general practitioners' surgeries. However, there appeared a sharp division in opinions on the use of MM-POC diagnostics at the patient's home (Figure 4), with
A
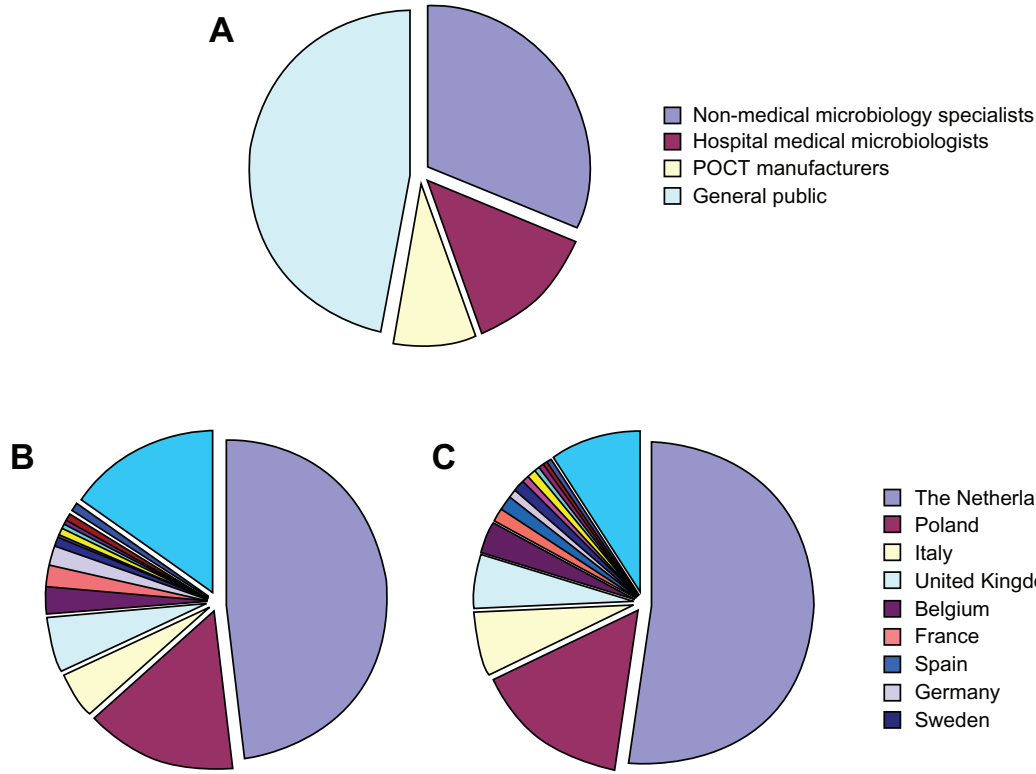

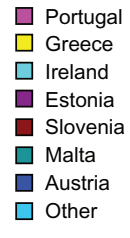

Figure 2 Profession (A), country born (B), and country of residence (C) of the 293 respondents who participated in the TEMPOtest-QC survey. Abbreviation: POCT, point-of-care test. 


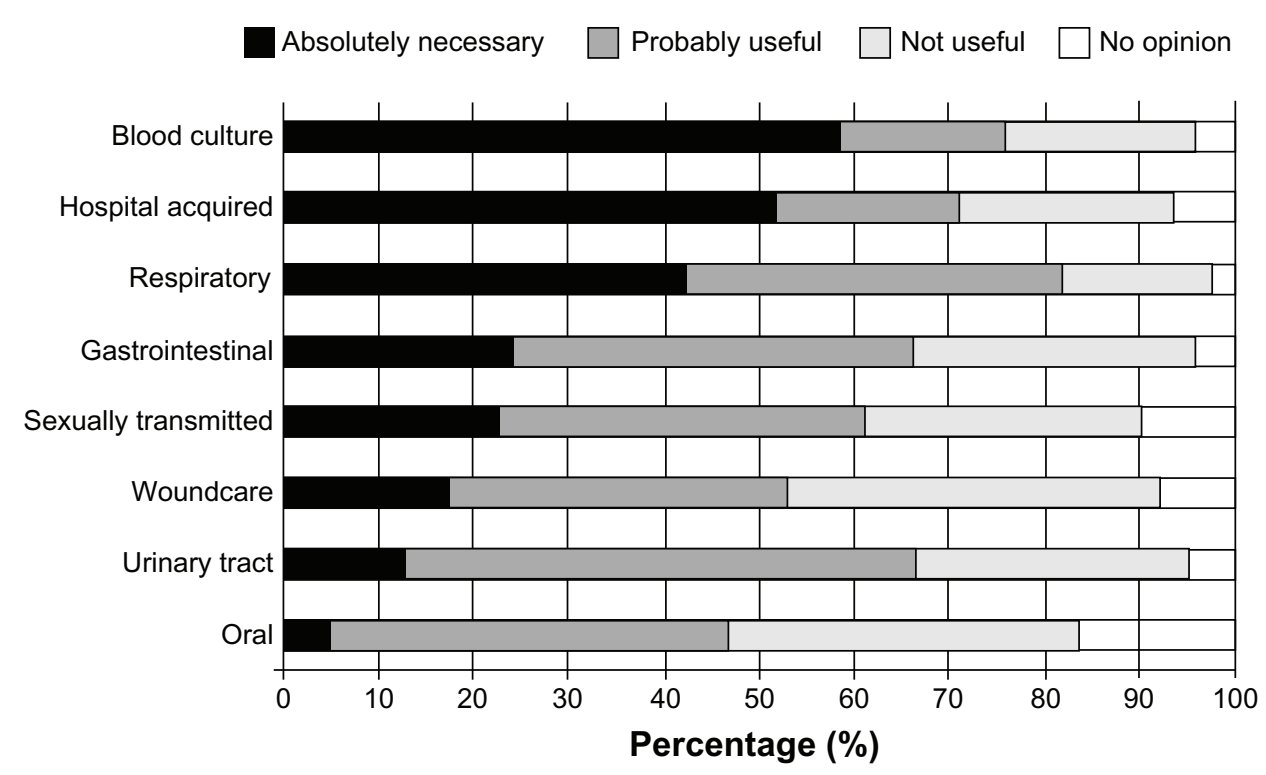

Figure 3 Mean responses of medical specialists regarding the current perceived necessity for MM-POC in relationship to type of disease. The majority regarded the development of MM-POC against both hospital acquired and blood culture infections as "Absolutely Necessary".

Abbreviation: MM-POC, medical microbiological point-of-care tests.

greater than $60 \%$ of the general public having a favorable opinion, compared to less than $20 \%$ of medical specialists.

When asked about their opinions regarding the actual specifications of bacterial/fungal POC diagnostics, medical specialists and POC manufacturers provided the responses shown in Table 1. Opinions on the most important factors with respect to an MM-POC device indicated that no single particular factor was considered most important in any of the target groups, though "reliability" and "time to diagnosis" tended to receive a large number of votes in both groups (both $60.8 \%)$. Interestingly, specificity scored high $(60.0 \%)$ in the medical specialists group but was least favored by the POC manufacturer group (44.0\%). Regarding the most important factors of an MM-POC device, no significant difference in the opinion of medical specialists and POCT manufacturers was observed $(P=0.54)$. Medical specialists opted for test specificity that could distinguish between bacteria, viruses, fungi and no infection (57.7\%) and class of antibiotic resistance

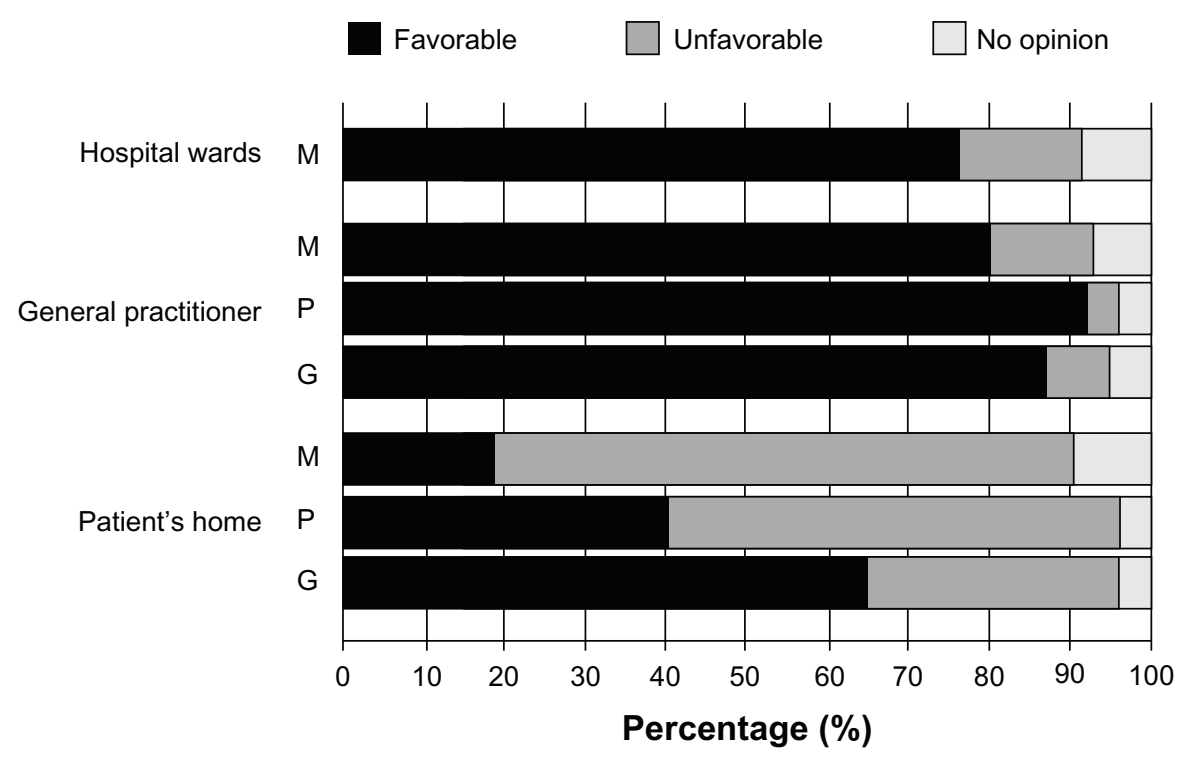

Figure 4 Opinions of target groups regarding the use of infectious disease (bacterial/fungal) POC devices in different environments. Medical specialists (hospital medical microbiologists and nonmedical microbiology specialists) (M), POCT manufacturers (P), and the general public (G) regarding the applicability of MM-POC in hospital wards, at the general practitioner or at the patient's home.

Abbreviations: G, general practitioners; M, medical specialists; P, POCT manufacturers; POCT, point-of-care test; MM-POC, medical microbiological point-of-care tests. 
Table I Opinions of target groups regarding the most relevant specifications for bacterial or fungal point-of-care diagnostics

\begin{tabular}{|c|c|c|c|c|}
\hline & $\begin{array}{l}\text { Medical specialists } \\
\text { No (\%) }\end{array}$ & $\begin{array}{l}\text { POCT manufacturers } \\
\text { No (\%) }\end{array}$ & OR $(95 \% \mathrm{Cl})$ & $P$-value \\
\hline Respondents & 130 & 25 & & \\
\hline \multicolumn{5}{|c|}{$\begin{array}{l}\text { I. In your opinion, what are the most important factors with respect to infectious disease POCT? } \\
\text { (multiple answers allowed). }\end{array}$} \\
\hline Costs & $70(53.8)$ & $17(68.0)$ & - & 0.543 \\
\hline Sensitivity & $78(60.0)$ & $14(56.0)$ & - & - \\
\hline Specificity & $78(60.0)$ & II (44.0) & - & - \\
\hline Simplicity & $69(53.1)$ & $19(76.0)$ & - & - \\
\hline Reliability & $79(60.8)$ & $19(76.0)$ & - & - \\
\hline Time to diagnosis & $79(60.8)$ & $21(84.0)$ & - & - \\
\hline \multicolumn{5}{|c|}{$\begin{array}{l}\text { 2. How specific should a bacterial or fungal POCT be? The test should be able to distinguish between: } \\
\text { (multiple answers allowed). }\end{array}$} \\
\hline Bacteria/fungi/viruses/no infection & $75(57.7)$ & $9(36.0)$ & - & 0.543 \\
\hline $\begin{array}{l}\text { Bacterial or fungal species including } \\
\text { genetic types/clones }\end{array}$ & $56(43.1)$ & $16(64.0)$ & - & - \\
\hline Class of antibiotic resistance & $94(72.3)$ & $12(48.0)$ & - & - \\
\hline No opinion & $9(6.9)$ & $2(8.0)$ & - & - \\
\hline \multicolumn{5}{|c|}{ 3. What would be your preferred maximum "time to diagnosis" for a bacterial or fungal POCT? } \\
\hline 0 minutes -5 minutes & $10(7.7)$ & $4(16.0)$ & $0.40(0.1 I-1.20)$ & 0.121 \\
\hline 5 minutes -15 minutes & $36(27.7)$ & $7(28.0)$ & $0.44(0.11-1.93)$ & 0.251 \\
\hline I5 minutes-I hour & $50(38.5)$ & $9(36.0)$ & $0.21(0.04-1.12)$ & 0.068 \\
\hline$>1$ hour & $32(24.6)$ & $3(12.0)$ & $0.42(0.11-1.77)$ & 0.206 \\
\hline \multicolumn{5}{|c|}{ 4. Complexity: In your opinion, what is the maximum number of processing steps that should be performed when using a bacterial or fungal POCT? } \\
\hline I step & $22(16.9)$ & $7(28.0)$ & $0.32(0.13-0.7 I)$ & 0.008 \\
\hline 2 steps & $47(36.2)$ & $5(20.0)$ & $0.32(0.09-1.1 I)$ & 0.075 \\
\hline 3 steps & $42(32.3)$ & $10(40.0)$ & $0.68(0.23-2.10)$ & 0.494 \\
\hline$>3$ steps & $16(12.3)$ & $3(12.0)$ & $0.45(0.09-1.85)$ & 0.289 \\
\hline
\end{tabular}

Abbreviations: $\mathrm{Cl}$, confidence interval; No, number; OR, odds ratio; $\mathrm{POCT}$, point-of-care test.

(72.3\%). A similar result was obtained among the POCT manufacturers. Interestingly both target groups tended to agree that any such MM-POC test should possess a maximum "time-to-diagnosis" of 15 min-1 hour. In addition, according to the target groups, the maximum number of processing steps for an MM-POC device was considered as 2 to 3 processing steps, which on average, when combined with the maximum time-to-diagnosis results described above, would suggest that an MM-POC device should require an average processing time of approximately 15 minutes per step.

\section{POC disease diagnosis at home} and the quality of healthcare

Table 2 shows the opinions of hospital personnel and the general public to questions relating to POC infectious disease diagnosis at home and the perceptions of these target groups regarding the quality of POC healthcare. The large majority of both medical specialists and the general public thought that the introduction of bacterial or fungal POC diagnostic testing to the general practi- tioner's surgery, or within the patient's own home, would affect the quality of patient care. However, the opinion on how patient care is affected significantly differed between the two target groups. The majority $(72.5 \%)$ of the general public expects that the use of MM-POC will allow the doctor to better monitor their health compared to less than half $(40.0 \%)$ of the medical specialists. The general public tended to be more positive regarding the effect of home POC testing on the doctor-patient relationship than the medical specialists. In fact, most medical specialists thought that bacterial or fungal home-testing POC technologies would indeed affect the doctor-patient relationship, with the majority of these (37/62) believing that any effect would result in a negative rather than a positive impact. Also the opinions on interpretation of the MM-POC test results differed between the two target groups. Whereas most $(53.1 \%)$ of the medical specialists expect problems in the interpretation of POC test results, a significantly smaller percentage $(37.0 \%)$ of the general public foresees problems. 
Table 2 Opinions of target groups regarding the effect of point-of-care testing on the quality of health care

\begin{tabular}{|c|c|c|c|c|}
\hline & $\begin{array}{l}\text { Medical specialists } \\
\text { No (\%) }\end{array}$ & $\begin{array}{l}\text { General public } \\
\text { No (\%) }\end{array}$ & OR $(95 \% \mathrm{CI})$ & $P$-value \\
\hline Respondents & 130 & 138 & & \\
\hline \multicolumn{5}{|c|}{$\begin{array}{l}\text { I. In your opinion, would the introduction of bacterial or fungal POC diagnostic testing to the general practitioner's surgery, or within the patient's } \\
\text { own home, affect the quality of patient care? }\end{array}$} \\
\hline Yes & $76(58.5)$ & $101(73.2)$ & $0.34(0.15-0.7 \mathrm{I})$ & 0.006 \\
\hline No & $28(21.5)$ & $28(20.3)$ & $2.79(1.14-7.27)$ & 0.028 \\
\hline Don't know & $24(18.5)$ & $9(6.5)$ & $3.47(1.59-8.22)$ & 0.003 \\
\hline \multicolumn{5}{|c|}{$\begin{array}{l}\text { 2. Do you think that home-testing using bacterial or fungal POC testing technologies will allow you/the doctor to better monitor your patients/your } \\
\text { health? }\end{array}$} \\
\hline Yes & $52(40.0)$ & $100(72.5)$ & $1.75(1.27-2.44)$ & $<0.000$ I \\
\hline No & $48(36.9)$ & $25(18.1)$ & $0.28(0.15-0.49)$ & $<0.0001$ \\
\hline Don't know & $28(21.5)$ & $13(10.0)$ & $0.24(0.11-0.48)$ & $<0.0001$ \\
\hline \multicolumn{5}{|c|}{ 3. Do you think that home-testing using bacterial or fungal POC technologies will have an impact on the doctor-patient relationship? } \\
\hline Yes (in a positive context) & $25(19.2)$ & $48(34.8)$ & $1.66(1.05-2.65)$ & 0.032 \\
\hline Yes (in a negative context) & $37(28.5)$ & $30(23.1)$ & $0.45(0.23-0.87)$ & 0.019 \\
\hline No & $27(20.8)$ & $35(25.4)$ & $0.73(0.37-1.43)$ & 0.359 \\
\hline \multirow[t]{2}{*}{ Don't know } & $39(30.0)$ & $25(18.1)$ & $0.37(0.18-0.72)$ & 0.004 \\
\hline & & & & 0.014 \\
\hline \multicolumn{5}{|c|}{ 4. Do you think that there will be significant problems in interpreting the results of bacterial or fungal POCT? } \\
\hline Yes & $69(53.1)$ & $51(37.0)$ & $0.68(0.47-0.97)$ & 0.033 \\
\hline No & $33(25.4)$ & $47(34.1)$ & $1.87(1.07-3.28)$ & 0.028 \\
\hline Don't know & $26(20.0)$ & $40(29.0)$ & $2.18(1.20-4.02)$ & 0.012 \\
\hline
\end{tabular}

Abbreviations: $\mathrm{Cl}$, confidence interval; No, number; OR, odds ratio; POC, point-of-care; POCT, point-of-care test.

\section{Infectious disease POC diagnostics and the general public}

One of the questions in the survey was related to the effect of MM-POC on patient visits to the general practitioner. The majority of the general public respondents (46.4\%) expect that the introduction of MM-POC tests will lead to a decrease in the number of visits they make to the general practitioner (Table 3). Additionally, if these MM-POC devices are to become available on the home testing market for the general public, information is required regarding the financial expectations of the general public towards the cost of such POC devices. The most favorable price for a single POC test currently lies between $€ 5$ to $€ 10$ (approximately $\$ 7.5-\$ 12.5$ ) per test (Table 3). Finally, $85.5 \%$ of the general public would be willing to purchase an MM-POC testing device at a pharmacy, rather than at a supermarket, at a drugstore, or over the internet (Table 3).

\section{Discussion}

The worldwide introduction and frequent use of infectious disease POC diagnostic devices (including bacterial/fungal testing), will help reduce the global infectious disease burden and help reduce the continuing development and spread of antimicrobial resistances. The TEMPOtest-QC questionnaire revealed that the development of MM-POC devices for the diagnosis of blood borne, hospital acquired, and respiratory tract infections should have the highest priority for POCT manufacturers. Moreover we would recommend POCT manufacturers to target MM-POC devices which are able to distinguish between bacteria/fungi/viruses/ no infection, and/or class of antibiotic resistance, with a maximum "time-to-diagnosis" of 15-60 minutes, in which a maximum of 2-3 processing steps are involved. All factors regarding infectious disease POC listed in the survey were scored with an equal importance by both medical specialists and POCT manufacturers. Interestingly, the only exception was specificity; this factor scored highest in the medical specialists group but was least favored by the POCT manufacturer group. Perhaps this is a factor that needs to be re-considered by POCT developers and manufacturers?

Surprisingly, "costs" tended not to be a top priority for both groups, though this was possibly due to the fact that the medical specialists were considering the use of MM-POC devices within a medical environment (hospital or general practitioner's surgery), rather than considering MM-POC devices intended for use in the much less mature 
Table 3 Perceived effect of the introduction of bacterial or fungal point-of-care testing technologies according to the general public

General public

No (\%)

Respondents

138

I. Do you think that home-testing using bacterial or fungal POCT technologies will likely increase or decrease the number of visits you make to your general practitioner?

Increase $16(11.6)$

Decrease $64(46.4)$

Have no effect $\quad 39(28.3)$

Don't know 19 (13.8)

2. If a home-testing kit for infectious diseases was available what is the maximum cost that you would be prepared to pay for a single test?

$€ 0$,-

$6(4.3)$

$€ 1,-$ to $€ 5$

$30(21.7)$

$€ 5,-$ to $€ 10$

$54(39.1)$

$€ 10,-$ to $€ 25$

$38(27.5)$

$€ 25,-$ to $€ 50$

$6(4.3)$

$€ 50,-$ to $€ 100$

$3(2.2)$

$>€ 100$

I (0.7)

3. Where would you prefer to purchase an infectious disease hometesting kit? (multiple choices allowed).

Your local hospital

$21(15.2)$

General practitioner

$42(30.4)$

Pharmacy

II 8 (85.5)

Drugstore

$48(34.8)$

Supermarket

$16(11.6)$

Internet

$19(13.8)$

Abbreviations: No, number; POCT, point-of-care test.

"home-testing" environment. Perhaps encouraging for POC manufacturers, the price that the general public is willing to pay is above the current price for a single POC test as declared by POCT manufacturers (data not shown). Though of course this price may have been calculated using discounts available from high-volume sales and high-throughput sampling, as opposed to the single-use testing that will be required for consumers within their own home. The purchase of an MMPOC device is by the majority of the general public favored at a pharmacy. This may be related to "trust issues", the general public perceiving medical products sold at pharmacies as being perhaps more "trustworthy" and of higher quality, as well as possibly valuing the expert advice available at pharmaceutical stores.

As a note of concern for POC manufacturers, respondents in the medical specialist and general public target groups were significantly different with respect to their opinions on whether there would be significant problems in interpreting the results of MM-POC diagnostic tests. In contrast, however, a clear majority of medical specialists thought that there would be significant problems in interpretation, a point of concern also raised in a previous study. ${ }^{20}$ These results indicate that careful design, unambiguous result interpretation, and ready access to reliable and understandable diagnostic information is a prerequisite for building consumer confidence in the use of POC diagnostics.

The authors acknowledge there is a bias in the national reporting levels between the different European countries in this study. However, at the moment there is no evidence to suggest that the opinions of Dutch and Polish responders are different to those of other European citizens. The authors also acknowledge that the responses from POCT manufacturers may be biased towards the rapid introduction of MM-POC devices to the infectious diseases diagnostic market. In fact, the responses from POCT manufacturers were similar to the opinions of those of medical professionals, and it is the favorable opinion of the general public, which is currently the driving force behind the development and implementation of such MM-POC devices.

In conclusion, in this survey, no significant differences were observed between the opinions of medical specialists and POC manufacturers regarding the most relevant specifications for MM-POC devices. However, interesting differences were observed in the responses to the introduction of MM-POC devices and their effect on the quality of healthcare, with the general public tending to be more optimistic about the effect of MM-POC device implementation and subsequent improvement in the quality of healthcare compared to the medical specialists. All of the above mentioned issues need to be addressed, in order to successfully understand the current requirements and perceived hurdles to the implementation of MM-POC diagnostic devices into the medical, and possibly home environment.

\section{Acknowledgments}

This research was funded as part of the European Union's Seventh Framework Programme FP7/2007-2013 (project TEMPOtest-QC, www.tempotest-qc.eu), under grant agreement no 241742. The authors would like to thank all respondents who took the time and effort to complete the online TEMPOtest-QC questionnaire. Their opinions are extremely valuable for the successful development and implementation of novel POC diagnostic devices. The authors would also like to thank B. Scharreman and F. Balvert of the Erasmus MC media group for their help and advice in making the TEMPOtest-QC video.

\section{Disclosure}

The authors report no conflicts of interest in this work. 


\section{References}

1. Yager P, Domingo GJ, Gerdes J. Point-of-care diagnostics for global health. Annu Rev Biomed Eng. 2008;10:107-144.

2. Riedel S, Carroll KC. Blood cultures: key elements for best practices and future directions. J Infect Chemother. 2010;16(5):301-316.

3. Jeong S, Park Y, Cho Y, Kim HS. Diagnostic utilities of procalcitonin and C-reactive protein for the prediction of bacteremia determined by blood culture. Clin Chim Acta. 2012;413(21-22):1731-1736.

4. Sakran JV, Michetti CP, Sheridan MJ, et al. The utility of procalcitonin in critically ill trauma patients. J Trauma Acute Care Surg. 2012;73(2): 413-418; discussion 418.

5. Nuutila J. Phagocytic Cell Surface Markers in Medical Microbiological Research and Diagnosis. In: Hays JP, van Leeuwen WB, editors. The Role of New Technologies in Medical Microbiological Research and Diagnosis. Dubai: Bentham Science; 2012:134-150.

6. Clerc O, Greub G. Routine use of point-of-care tests: usefulness and application in clinical microbiology. Clin Microbiol Infect. 2010;16(8): 1054-1061.

7. Afshari A, Schrenzel J, Ieven M, Harbarth S. Bench-to-bedside review: Rapid molecular diagnostics for bloodstream infection - a new frontier? Crit Care. 2012;16(3):222.

8. Bissonnette L, Bergeron MG. Diagnosing infections - current and anticipated technologies for point-of-care diagnostics and home-based testing. Clin Microbiol Infect. 2010;16(8):1044-1053.

9. Reischl U, Schmitz RPH. In search of a new gold standard - a technical review of molecular approaches to improve early diagnosis of microbialinduced sepsis. Eur Infect Dis. 2001;5(1):44-46.

10. Mogensen CB, Borch A, Brandslund I. Point of care technology or standard laboratory service in an emergency department: is there a difference in time to action? A randomised trial. Scand J Trauma Resusc Emerg Med. 2011;19:49.
11. Price CP. Point of care testing. BMJ. 2001;322(7297):1285-1288.

12. Charles PG. Early diagnosis of lower respiratory tract infections (pointof-care tests). Curr Opin Pulm Med. 2008;14(3):176-182.

13. Cals JW, Chappin FH, Hopstaken RM, et al. C-reactive protein point-ofcare testing for lower respiratory tract infections: a qualitative evaluation of experiences by GPs. Fam Pract. 2010;27(2):212-218.

14. Snydman DR. Empiric antibiotic selection strategies for healthcareassociated pneumonia, intra-abdominal infections, and catheterassociated bacteremia. J Hosp Med. 2012;7(S1):S2-S12.

15. Opal SM, Calandra T. Antibiotic usage and resistance: gaining or losing ground on infections in critically ill patients?. JAMA. 2009;302(21): 2367-2368.

16. Holden MJ, Madej RM, Minor P, Kalman LV. Molecular diagnostics: harmonization through reference materials, documentary standards and proficiency testing. Expert Rev Mol Diagn. 2011;11(7):741-755.

17. Pai NP, Vadnais C, Denkinger C, Engel N, Pai M. Point-of-care testing for infectious diseases: diversity, complexity, and barriers in low- and middle-income countries. PLoS Med. 2012;9(9):e1001306.

18. Palamountain KM, Baker J, Cowan EP, et al. Perspectives on introduction and implementation of new point-of-care diagnostic tests. $J$ Infect Dis. 2012;205 Suppl 2:S181-S190.

19. R Core Team (2012). R: A language and environment for statistical computing. R Foundation for Statistical Computing, Vienna, Austria. Available from: http://www.R-project.org/.

20. Wood F, Brookes-Howell L, Hood K, et al. A multi-country qualitative study of clinicians' and patients' views on point of care tests for lower respiratory tract infection. Fam Pract. 2011;28(6):661-669. 


\section{Supplemental data appendix S I}

Nonmedical microbiology specialist (hospital doctors and nurses)

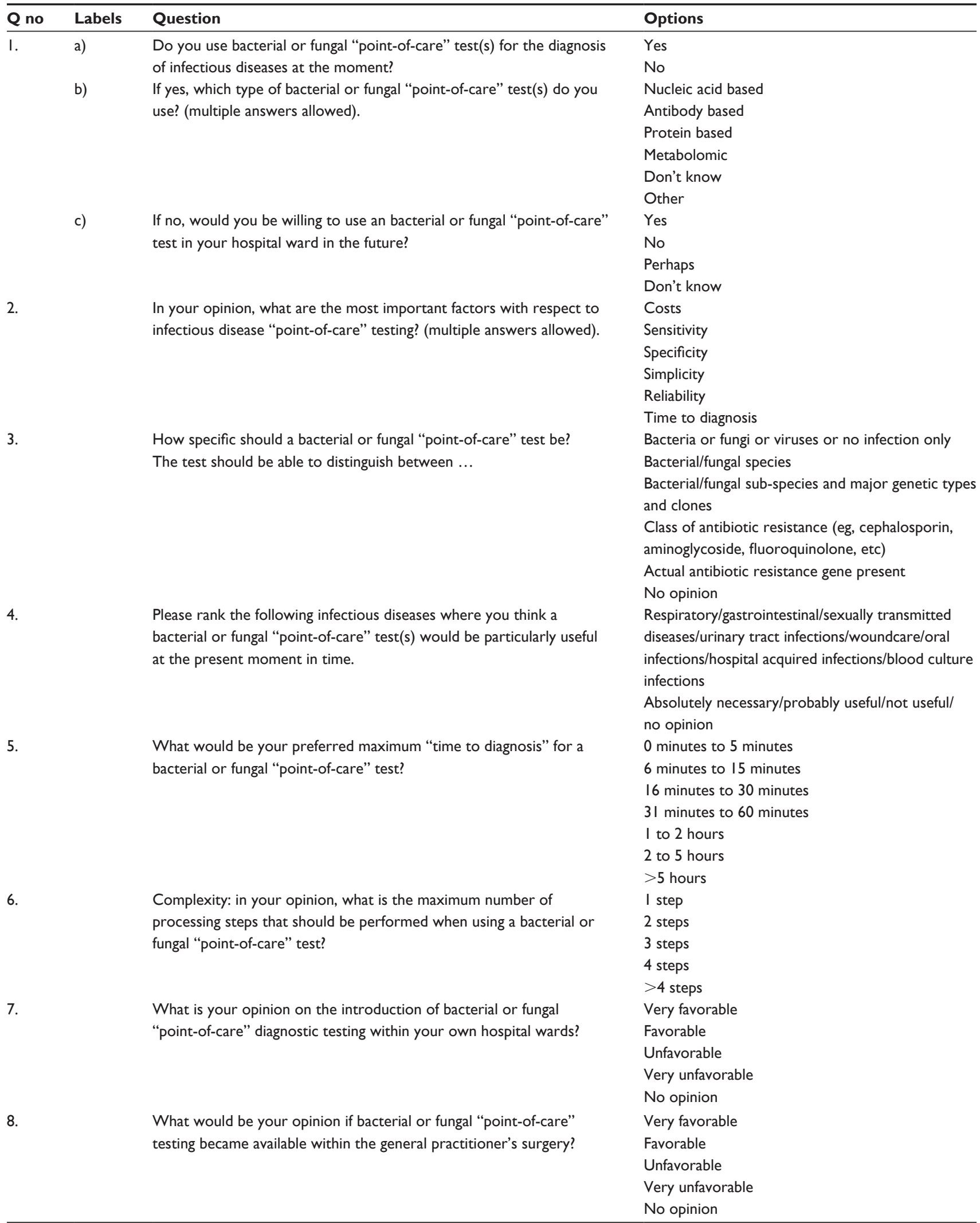


Nonmedical microbiology specialist (hospital doctors and nurses) (Continued)

\begin{tabular}{ll}
\hline Q no $\quad$ Labels & Question \\
\hline 9. & $\begin{array}{l}\text { What would be your opinion if bacterial or fungal "point-of-care" } \\
\text { testing became available within the patient's own home (with patients } \\
\text { able to perform their own diagnostic testing)? }\end{array}$ \\
I0. a) & $\begin{array}{l}\text { In your opinion, would the introduction of bacterial or fungal "point- } \\
\text { of-care" testing to hospital wards (to be performed by nonmedical } \\
\text { microbiology specialist doctors and nurses), affect your professional } \\
\text { status? }\end{array}$
\end{tabular}

If yes, how do you think it would affect your professional status?

II. Do you think that home-testing using bacterial or fungal point-of-care testing technologies will:

a)

b)

c)

12.

13.

14.

a)

b)

15.

Do you believe that the use of bacterial and fungal "point-of-care" test(s) will positively or negatively affect how patients view your profession?

\author{
Options \\ Very favorable \\ Favorable \\ Unfavorable \\ Very unfavorable \\ No opinion \\ Definitely yes \\ Yes \\ No \\ Definitely no \\ Don't know \\ Very positively \\ Positively \\ Negatively \\ Very negatively \\ Don't know
}

Yes

No

Don't know

Yes

No

Don't know

Yes (in a positive context)

Yes (in a negative context)

No

Don't know

Yes

No

Don't know

Definitely yes

Yes

No

Definitely no

Don't know

Very favorable

Favorable

Unfavorable

Very unfavorable

No opinion

Very favorable

Favorable

Unfavorable

Very unfavorable

No opinion

Very positively

Positively

Negatively

Very negatively

Don't know

No effect 
Hospital medical microbiologists including medical microbiology laboratory technicians

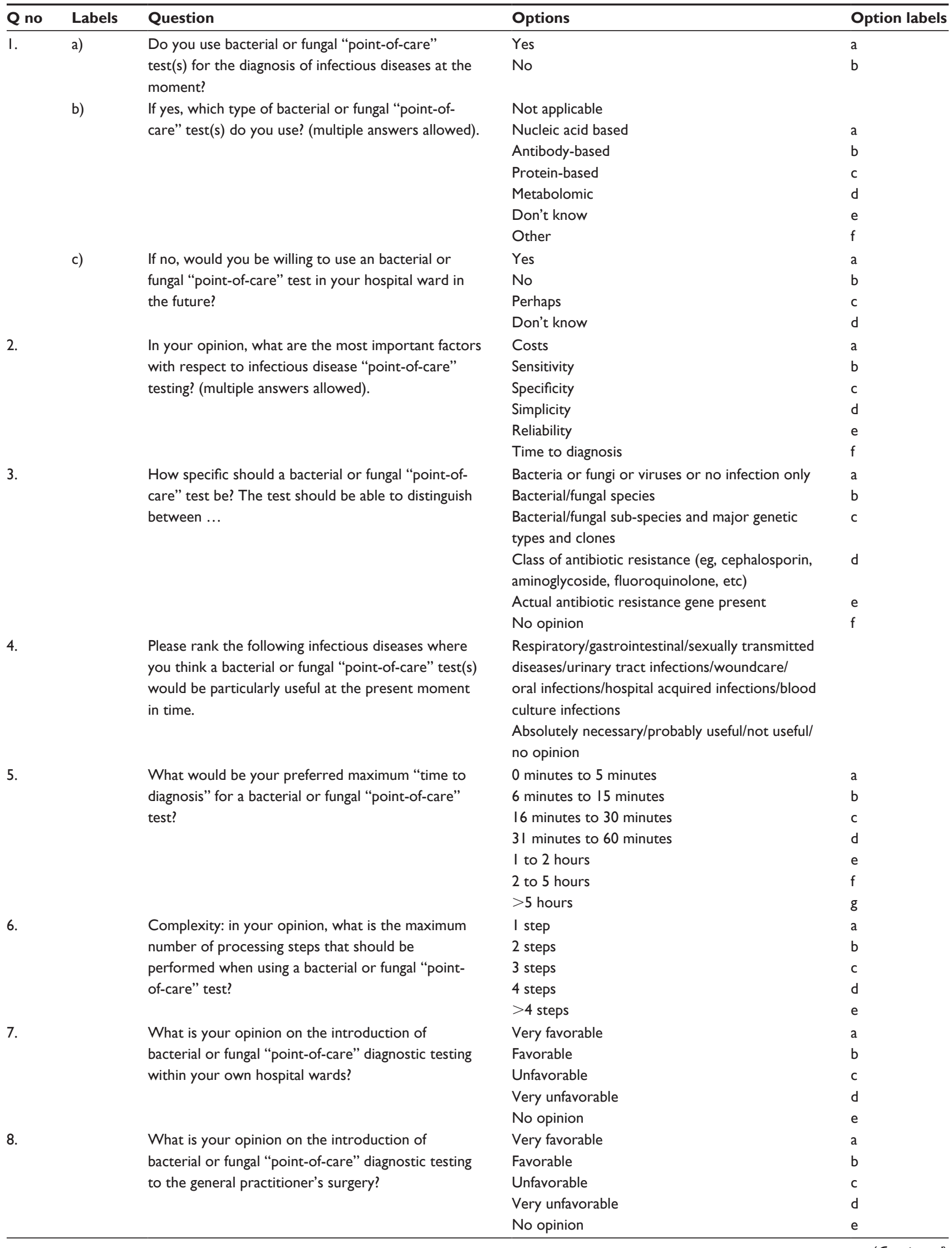

(Continued) 
Hospital medical microbiologists including medical microbiology laboratory technicians (Continued)

\begin{tabular}{|c|c|c|c|c|}
\hline Q no & Labels & Question & Options & Option labels \\
\hline \multirow[t]{5}{*}{9.} & & What would be your opinion if bacterial or fungal & Very favorable & a \\
\hline & & "point-of-care" diagnostic testing became available & Favorable & b \\
\hline & & within the patient's own home (with patients able to & Unfavorable & c \\
\hline & & perform their own diagnostic testing)? & Very unfavorable & $d$ \\
\hline & & & No opinion & e \\
\hline \multirow[t]{10}{*}{10.} & a) & In your opinion, would the introduction of bacterial & Definitely yes & $\mathrm{a}$ \\
\hline & & or fungal "point-of-care" testing to hospital wards (to & Yes & $\mathrm{b}$ \\
\hline & & be performed by nonmedical microbiology specialist & No & c \\
\hline & & doctors and nurses), affect your professional status? & Definitely no & $d$ \\
\hline & & & Don't know & e \\
\hline & b) & If yes, how do you think it would affect your & Very positively & a \\
\hline & & professional status? & Positively & b \\
\hline & & & Negatively & c \\
\hline & & & Very negatively & $d$ \\
\hline & & & Don't know & e \\
\hline \multirow[t]{18}{*}{ II. } & & Do you think that home-testing using bacterial or & & \\
\hline & & fungal "point-of-care" testing technologies will: & & \\
\hline & a) & Allow you to better monitor your patients' health? & Yes & $\mathrm{a}$ \\
\hline & & & No & $b$ \\
\hline & & & Don't know & c \\
\hline & b) & Allow patients to better monitor their health? & Yes & $\mathrm{a}$ \\
\hline & & & No & b \\
\hline & & & Don't know & c \\
\hline & c) & Increase or decrease the number of visits patients & Greatly increase & $\mathrm{a}$ \\
\hline & & make to their general practitioner? & Increase & $\mathrm{b}$ \\
\hline & & & Decrease & c \\
\hline & & & Greatly decrease & d \\
\hline & & & Have no effect & e \\
\hline & & & Don't know & f \\
\hline & d) & Impact on the doctor-patient relationship? & Yes (in a positive context) & a \\
\hline & & & Yes (in a negative context) & b \\
\hline & & & No & c \\
\hline & & & Don't know & $d$ \\
\hline \multirow[t]{3}{*}{12.} & & Do you think that there will be significant problems & Yes & $\mathrm{a}$ \\
\hline & & in interpretating the results of bacterial or fungal & No & $b$ \\
\hline & & "point-of-care" diagnostic tests? & Don't know & c \\
\hline \multirow[t]{5}{*}{13.} & & In your opinion, would the introduction of bacterial & Definitely yes & $\mathrm{a}$ \\
\hline & & or fungal "point-of-care" diagnostic testing to the & Yes & b \\
\hline & & general practitioner's surgery, or within the patient's & No & c \\
\hline & & own home, affect the quality of patient care? & Definitely no & d \\
\hline & & & Don't know & e \\
\hline \multirow[t]{11}{*}{14.} & & What is your opinion on the following statements: & & \\
\hline & a) & "Infectious disease home-testing kits are being & Very favorable & $\mathrm{a}$ \\
\hline & & developed that will allow people to test themselves & Favorable & $b$ \\
\hline & & at home without medical supervision for the & Unfavorable & c \\
\hline & & presence of infectious diseases?" & Very unfavorable & $d$ \\
\hline & & & No opinion & e \\
\hline & b) & "Test-kits are being developed that will allow people & Very favorable & $\mathrm{a}$ \\
\hline & & to be tested at their own general practitioner's & Favorable & b \\
\hline & & surgery for the presence of infectious diseases?" & Unfavorable & c \\
\hline & & & Very unfavorable & $d$ \\
\hline & & & No opinion & e \\
\hline \multirow[t]{6}{*}{15.} & & Do you believe that the use of bacterial and fungal & Very positively & $\mathrm{a}$ \\
\hline & & point-of-care test(s) will positively or negatively & Positively & $b$ \\
\hline & & affect how patients view your profession? & Negatively & c \\
\hline & & & Very negatively & $d$ \\
\hline & & & Don't know & e \\
\hline & & & No effect & f \\
\hline
\end{tabular}


Hospital medical microbiologists including medical microbiology laboratory technicians (Continued)

\begin{tabular}{|c|c|c|c|c|}
\hline Q no & Labels & Question & Options & Option labels \\
\hline \multirow[t]{5}{*}{16.} & & In your opinion, would the introduction of bacterial & Definitely yes & a \\
\hline & & or fungal "point-of-care" diagnostic testing to the & Yes & $\mathrm{b}$ \\
\hline & & general practitioner's surgery, or within the patient's & No & c \\
\hline & & own home, affect the jobs of currently employed & Definitely no & $d$ \\
\hline & & medical microbiologists? & Don't know & e \\
\hline \multirow[t]{5}{*}{17.} & & In your opinion, would there still be a role for & Definitely yes & a \\
\hline & & qualified hospital medical microbiologists and & Yes & b \\
\hline & & trained medical microbiology diagnostic laboratory & No & c \\
\hline & & technicians if bacterial or fungal "point-of-care" & Definitely no & d \\
\hline & & $\begin{array}{l}\text { diagnostic testing became widely available and used in } \\
\text { hospital wards, in general practitioners surgeries, and } \\
\text { at home by patients? }\end{array}$ & Don't know & e \\
\hline
\end{tabular}

Point-of-care test manufacturers

\begin{tabular}{|c|c|c|}
\hline Q no & Labels & Question \\
\hline I. & & $\begin{array}{l}\text { Which type of bacterial or fungal "point-of- } \\
\text { care" test (including tests available to general } \\
\text { practitioners, hospital laboratories, and in the } \\
\text { home) do you currently have available on the } \\
\text { market? (multiple answers allowed). }\end{array}$ \\
\hline
\end{tabular}

2.

3.

4. a)

a) For which disease type(s) have you developed, or are you developing, a "point-of-care" test? (multiple answers allowed).

b)

Which infectious disease type is likely to be most profitable for manufacturers of infectious disease "point-of-care" tests? Please rank in order of importance.

\begin{tabular}{|c|c|}
\hline Options & Option labels \\
\hline Nucleic acid based & a \\
\hline Antibody based & b \\
\hline Protein based & c \\
\hline Metabolomic & $d$ \\
\hline Other & e \\
\hline No test currently available & $f$ \\
\hline Costs & a \\
\hline Sensitivity & b \\
\hline Specificity & c \\
\hline Simplicity & $d$ \\
\hline Reliability & e \\
\hline Time to diagnosis & $f$ \\
\hline $\begin{array}{l}\text { Bacteria or fungi or viruses or no } \\
\text { infection only }\end{array}$ & a \\
\hline Bacterial/fungal species & b \\
\hline $\begin{array}{l}\text { Bacterial/fungal sub-species and major } \\
\text { genetic types and clones }\end{array}$ & c \\
\hline $\begin{array}{l}\text { Class of antibiotic resistance (eg, } \\
\text { cephalosporin, aminoglycoside, } \\
\text { fluoroquinolone, etc) }\end{array}$ & $d$ \\
\hline $\begin{array}{l}\text { Actual antibiotic resistance gene } \\
\text { present }\end{array}$ & e \\
\hline No opinion & $f$ \\
\hline Respiratory & a \\
\hline Gastrointestinal & $b$ \\
\hline Sexually transmitted diseases & c \\
\hline Urinary tract infections & d \\
\hline Woundcare & e \\
\hline Oral infections & $f$ \\
\hline Hospital acquired infections & g \\
\hline Blood culture infections & $\mathrm{h}$ \\
\hline None & $\mathrm{i}$ \\
\hline Confidential & j \\
\hline Respiratory & $\begin{array}{l}\text { Absolutely necessary/probably } \\
\text { useful/not useful/no opinion }\end{array}$ \\
\hline Gastrointestinal & $\begin{array}{l}\text { Absolutely necessary/probably } \\
\text { useful/not useful/no opinion }\end{array}$ \\
\hline Sexually transmitted diseases & $\begin{array}{l}\text { Absolutely necessary/probably } \\
\text { useful/not useful/no opinion }\end{array}$ \\
\hline
\end{tabular}

(Continued) 


\begin{tabular}{|c|c|c|c|c|}
\hline Q no & Labels & Question & Options & Option labels \\
\hline & & & Urinary tract infections & Absolutely necessary/probably \\
\hline & & & & useful/not useful/no opinion \\
\hline & & & Woundcare & $\begin{array}{l}\text { Absolutely necessary/probably } \\
\text { useful/not useful/no opinion }\end{array}$ \\
\hline & & & Oral infections & Absolutely necessary/probably \\
\hline & & & & useful/not useful/no opinion \\
\hline & & & Hospital acquired infections & Absolutely necessary/probably \\
\hline & & & & useful/not useful/no opinion \\
\hline & & & Blood culture infections & Absolutely necessary/probably \\
\hline & & & & useful/not useful/no opinion \\
\hline \multirow[t]{10}{*}{5.} & & How long do you estimate the time to diagnosis & 0 minutes to 5 minutes & a \\
\hline & & for your bacterial or fungal "point-of-care" test & 6 minutes to 15 minutes & b \\
\hline & & to be? & 16 minutes to 30 minutes & c \\
\hline & & & 31 minutes to 60 minutes & d \\
\hline & & & I to 2 hours & e \\
\hline & & & 2 to 5 hours & $f$ \\
\hline & & & $>5$ hours & $g$ \\
\hline & & & Not known & h \\
\hline & & & Confidential & $\mathrm{i}$ \\
\hline & & & Not applicable & j \\
\hline \multirow[t]{5}{*}{6.} & & Complexity: in your opinion, what is the & I step & a \\
\hline & & maximum number of processing steps that & 2 steps & $\mathrm{b}$ \\
\hline & & should be performed when using a bacterial or & 3 steps & c \\
\hline & & fungal "point-of-care" test? & 4 steps & $d$ \\
\hline & & & $>4$ steps & e \\
\hline \multirow[t]{10}{*}{7.} & & How much does your "point-of-care" cost & $€ 0,-$ per test & a \\
\hline & & (per test) on the market (in euro)? & $€ \mathrm{I},-$ to $€ 5,-$ per test & b \\
\hline & & & $€ 6,-$ to $€ 10,-$ per test & c \\
\hline & & & $€ I I,-$ to $€ 25,-$ per test & $d$ \\
\hline & & & $€ 26,-$ to $€ 50,-$ per test & e \\
\hline & & & $€ 51,-$ to $€ 100,-$ per test & $f$ \\
\hline & & & $>€ 100,-$ per test & $g$ \\
\hline & & & Not known & $\mathrm{h}$ \\
\hline & & & Confidential & $\mathrm{i}$ \\
\hline & & & Not applicable & j \\
\hline \multirow[t]{5}{*}{8.} & & In your opinion, would the introduction of & Definitely yes & a \\
\hline & & bacterial or fungal "point-of-care" diagnostic & Yes & $\mathrm{b}$ \\
\hline & & testing to the general practitioner's surgery, or & No & c \\
\hline & & within the patient's own home, affect the quality & Definitely no & $d$ \\
\hline & & of patient care? & Don't know & e \\
\hline \multirow[t]{11}{*}{9.} & & What is your opinion on the following statements: & & \\
\hline & a) & "Infectious disease home-testing kits are & Very favorable & a \\
\hline & & being developed that will allow people to & Favorable & $\mathrm{b}$ \\
\hline & & test themselves at home without medical & Unfavorable & c \\
\hline & & supervision for the presence of infectious & Very unfavorable & d \\
\hline & & diseases?" & No opinion & e \\
\hline & b) & "Test-kits are being developed that will allow & Very favorable & a \\
\hline & & people to be tested at their own general & Favorable & $\mathrm{b}$ \\
\hline & & practitioner's surgery for the presence of & Unfavorable & c \\
\hline & & infectious diseases?" & Very unfavorable & $d$ \\
\hline & & & No opinion & e \\
\hline \multirow[t]{6}{*}{10.} & & Do you believe that the use of bacterial and & Very positively & a \\
\hline & & fungal point-of-care test(s) will positively & Positively & $\mathrm{b}$ \\
\hline & & or negatively affect how patients view your & Negatively & c \\
\hline & & profession? & Very negatively & d \\
\hline & & & Don't know & e \\
\hline & & & No effect & f \\
\hline
\end{tabular}


Point-of-care test manufacturers (Continued)

\begin{tabular}{|c|c|c|c|c|}
\hline Q no & Labels & Question & Options & Option labels \\
\hline \multirow[t]{7}{*}{ II. } & & Which type of bacterial or fungal "point-of- & Nucleic acid based & $\mathrm{a}$ \\
\hline & & care" test (including tests available to general & Antibody based & $b$ \\
\hline & & practitioners, hospital laboratories, and in the & Protein based & c \\
\hline & & home) are you currently developing? (multiple & Metabolomic & $d$ \\
\hline & & answers allowed). & Other & $\mathrm{e}$ \\
\hline & & & No test currently available & $f$ \\
\hline & & & Confidential & $g$ \\
\hline \multirow[t]{5}{*}{12.} & & For which market have you, or are you, & General practitioners & $\mathrm{a}$ \\
\hline & & developing your bacterial or fungal "point-of- & Hospital laboratories & $\mathrm{b}$ \\
\hline & & care" tests? & Home use & c \\
\hline & & & Confidential & $d$ \\
\hline & & & Not applicable & $\mathrm{e}$ \\
\hline \multirow[t]{7}{*}{13.} & & Which factors would/do you take into & Size of target audience & $\mathrm{a}$ \\
\hline & & consideration if/when developing new bacterial & Profit margin & $\mathrm{b}$ \\
\hline & & or fungal "point-of-care" tests? Please rank in & Prevalence of disease & c \\
\hline & & importance. & Costs of manufacture & $d$ \\
\hline & & & Ease of use for the end-user & $\mathrm{e}$ \\
\hline & & & Costs of kit development & $f$ \\
\hline & & & Reputation of kit manufacturer & $g$ \\
\hline \multirow[t]{8}{*}{14.} & & Which factor(s) do you think are the most & Cost per test & $\mathrm{a}$ \\
\hline & & important in influencing hospitals and general & Simplicity of test methodology & $b$ \\
\hline & & practitioners to use bacterial or fungal "point- & Speed of diagnosis & c \\
\hline & & of-care" tests for a diagnostics laboratory? & Robustness and reliability of the test kit & $d$ \\
\hline & & Please rank in importance. & Ease of use for the end-user & $\mathrm{e}$ \\
\hline & & & Reputation of the manufacturer & $f$ \\
\hline & & & Sensitivity & $g$ \\
\hline & & & Specificity & $\mathrm{h}$ \\
\hline
\end{tabular}

General public

\begin{tabular}{|c|c|c|c|c|}
\hline Q no & Labels & Question & Options & Option labels \\
\hline \multirow[t]{5}{*}{ I. } & & What is your opinion on the use of infectious disease home-testing-kits that & Very favorable & a \\
\hline & & would allow you to monitor your health at home? & Favorable & $\mathrm{b}$ \\
\hline & & & Unfavorable & c \\
\hline & & & Very unfavorable & d \\
\hline & & & No opinion & e \\
\hline \multirow[t]{7}{*}{2.} & & If a home-testing kit for infectious diseases was available, what is the & 0 minutes to 5 minutes & a \\
\hline & & maximum time that you would be prepared to wait for a result? & 6 minutes to 15 minutes & $\mathrm{b}$ \\
\hline & & & 16 minutes to 30 minutes & c \\
\hline & & & 31 minutes to 60 minutes & d \\
\hline & & & I to 2 hours & e \\
\hline & & & 2 to 5 hours & $f$ \\
\hline & & & $>5$ hours & g \\
\hline \multirow[t]{7}{*}{3.} & & If a home-testing kit for infectious diseases was available (and you had to & $€ 0,-$ per test & a \\
\hline & & purchase the kit yourself) what is the maximum cost that you would be & $€ 1,-$ to $€ 5,-$ per test & $\mathrm{b}$ \\
\hline & & prepared to pay for a single test (in euro)? & $€ 6,-$ to $€ 10,-$ per test & c \\
\hline & & & $€ I I,-$ to $€ 25,-$ per test & d \\
\hline & & & $€ 26,-$ to $€ 50,-$ per test & e \\
\hline & & & $€ 51,-$ to $€ 100,-$ per test & $f$ \\
\hline & & & $>€ 100,-$ per test & $g$ \\
\hline \multirow[t]{4}{*}{4.} & & $\begin{array}{l}\text { Do you think that home-testing using bacterial or fungal "point-of-care" } \\
\text { testing technologies will: }\end{array}$ & & \\
\hline & a) & Allow you to better monitor your health? & Yes & a \\
\hline & & & No & $\mathrm{b}$ \\
\hline & & & Don't know & c \\
\hline
\end{tabular}

(Continued) 
General public (Continued)

\begin{tabular}{|c|c|c|c|c|}
\hline Q no & Labels & Question & Options & Option labels \\
\hline & \multirow[t]{3}{*}{ b) } & \multirow[t]{3}{*}{ Allow a doctor to better monitor your health? } & Yes & a \\
\hline & & & No & $\mathrm{b}$ \\
\hline & & & Don't know & c \\
\hline & \multirow[t]{6}{*}{ c) } & \multirow{6}{*}{$\begin{array}{l}\text { Likely increase or decrease the number of visits you make to your general } \\
\text { practitioner? }\end{array}$} & Greatly increase & $\mathrm{a}$ \\
\hline & & & Increase & b \\
\hline & & & Decrease & c \\
\hline & & & Greatly decrease & $d$ \\
\hline & & & Have no effect & e \\
\hline & & & Don't know & f \\
\hline & \multirow[t]{7}{*}{ d) } & \multirow[t]{4}{*}{ Impact on the doctor-patient relationship? } & Yes (in a positive context) & a \\
\hline & & & Yes (in a negative context) & $\mathrm{b}$ \\
\hline & & & No & c \\
\hline & & & Don't know & $d$ \\
\hline \multirow[t]{3}{*}{5.} & & Do you think that there will be significant problems in interpretating the & Yes & a \\
\hline & & results of bacterial or fungal "point-of-care" diagnostic tests? & No & b \\
\hline & & & Don't know & c \\
\hline \multirow[t]{5}{*}{6.} & & In your opinion, would the introduction of bacterial or fungal "point-of-care" & Definitely yes & a \\
\hline & & diagnostic testing to the general practitioner's surgery, or within the patient's & Yes & b \\
\hline & & own home, affect the quality of your health care? & No & c \\
\hline & & & Definitely no & d \\
\hline & & & Don't know & e \\
\hline \multirow[t]{11}{*}{7.} & & What is your opinion on the following statements: & & \\
\hline & a) & "Infectious disease home-testing kits are being developed that will allow & Very favorable & $\mathrm{a}$ \\
\hline & & people to test themselves at home without medical supervision for the & Favorable & b \\
\hline & & presence of infectious diseases?" & Unfavorable & c \\
\hline & & & Very unfavorable & d \\
\hline & & & No opinion & e \\
\hline & b) & "Test-kits are being developed that will allow people to be tested at their & Very favorable & a \\
\hline & & own general practitioner's surgery for the presence of infectious diseases?" & Favorable & b \\
\hline & & & Unfavorable & c \\
\hline & & & Very unfavorable & d \\
\hline & & & No opinion & e \\
\hline \multirow[t]{6}{*}{8.} & & If not available for free, where would you prefer to buy an infectious & Your local hospital & $\mathrm{a}$ \\
\hline & & disease home-testing kit? (multiple choices allowed). & General practitioner & b \\
\hline & & & Pharmacy & c \\
\hline & & & Drugstore & $d$ \\
\hline & & & Supermarket & e \\
\hline & & & Internet & $f$ \\
\hline
\end{tabular}

General practitioners

\begin{tabular}{llll}
\hline Q no & Labels & Question & Options \\
\hline I. & a) & Do you use bacterial or fungal "point-of-care" test(s) for the & Yes \\
& & diagnosis of infectious diseases at the moment? & No \\
& b) & $\begin{array}{l}\text { If yes, which type of bacterial or fungal "point-of-care" test(s) } \\
\text { do you use? (multiple answers allowed). }\end{array}$ & Nucleic acid based \\
& & Antibody based & Protein based \\
& & Metabolomic \\
& & Don't know \\
& & Other \\
& & & Yes \\
& If no, would you consider using and infectious disease & No \\
& "point-of-care" test in your practice in the future? & Perhaps \\
& & Don't know \\
\hline
\end{tabular}




\section{General practitioners (Continued)}

\begin{tabular}{|c|c|c|c|}
\hline Q no & Labels & Question & Options \\
\hline 2. & & $\begin{array}{l}\text { In your opinion, what are the most important factors with } \\
\text { respect to bacterial or fungal "point-of-care" testing? (multiple } \\
\text { answers allowed). }\end{array}$ & $\begin{array}{l}\text { Costs } \\
\text { Sensitivity } \\
\text { Specificity } \\
\text { Simplicity } \\
\text { Reliability } \\
\text { Time to diagnosis }\end{array}$ \\
\hline 3. & & $\begin{array}{l}\text { How specific should a bacterial or fungal "point-of-care" test } \\
\text { be? The test should be able to distinguish between ... }\end{array}$ & $\begin{array}{l}\text { Bacteria or fungi or viruses or no infection only } \\
\text { Bacterial/fungal species } \\
\text { Bacterial/fungal sub-species and major genetic types and } \\
\text { clones } \\
\text { Class of antibiotic resistance (eg, cephalosporin, } \\
\text { aminoglycoside, fluoroquinolone, etc) } \\
\text { Actual antibiotic resistance gene present } \\
\text { No opinion }\end{array}$ \\
\hline 4. & & $\begin{array}{l}\text { Please rank the following infectious diseases where you think } \\
\text { bacterial or fungal "point-of-care" test(s) would be particularly } \\
\text { useful at the present moment in time. }\end{array}$ & $\begin{array}{l}\text { Respiratory/gastrointestinal/sexually transmitted diseases/ } \\
\text { urinary tract infections/woundcare/oral infections/hospital } \\
\text { acquired infections/blood culture infections } \\
\text { Absolutely necessary/probably useful/not useful/no opinion }\end{array}$ \\
\hline 5. & & $\begin{array}{l}\text { What would be the maximum useful "time to diagnosis" for an } \\
\text { bacterial or fungal "point-of-care" test? }\end{array}$ & $\begin{array}{l}0 \text { minutes to } 5 \text { minutes } \\
6 \text { minutes to } 15 \text { minutes } \\
16 \text { minutes to } 30 \text { minutes } \\
31 \text { minutes to } 60 \text { minutes } \\
\text { I to } 2 \text { hours } \\
2 \text { to } 5 \text { hours } \\
>5 \text { hours }\end{array}$ \\
\hline 6. & & $\begin{array}{l}\text { Complexity: in your opinion, what is the maximum number } \\
\text { of processing steps that should be performed when using a } \\
\text { bacterial or fungal "point-of-care" test? }\end{array}$ & $\begin{array}{l}\text { I step } \\
2 \text { steps } \\
3 \text { steps } \\
4 \text { steps } \\
>4 \text { steps }\end{array}$ \\
\hline 7. & & $\begin{array}{l}\text { What in your opinion should be the current maximum cost } \\
\text { per test for a bacterial or fungal "point-of-care" test (in euro)? }\end{array}$ & $\begin{array}{l}€ 0,- \text { per test } \\
€ I,- \text { to } € 5,- \text { per test } \\
€ 6,- \text { to } € 10,- \text { per test } \\
€ 11,- \text { to } € 25,- \text { per test } \\
€ 26,- \text { to } € 50,- \text { per test } \\
€ 51,- \text { to } € 100,- \text { per test } \\
>€ 100,- \text { per test }\end{array}$ \\
\hline 8. & & $\begin{array}{l}\text { What is your opinion on the introduction of bacterial or fungal } \\
\text { "point-of-care" diagnostic testing to the general practitioner's } \\
\text { surgery? }\end{array}$ & $\begin{array}{l}\text { Very favorable } \\
\text { Favorable } \\
\text { Unfavorable } \\
\text { Very unfavorable } \\
\text { No opinion }\end{array}$ \\
\hline 9. & & $\begin{array}{l}\text { What would be your opinion if bacterial or fungal "point-of- } \\
\text { care" diagnostic testing became available within the patient's } \\
\text { own home (with patients able to perform their own diagnostic } \\
\text { testing)? }\end{array}$ & $\begin{array}{l}\text { Very favorable } \\
\text { Favorable } \\
\text { Unfavorable } \\
\text { Very unfavorable } \\
\text { No opinion }\end{array}$ \\
\hline 10. & & $\begin{array}{l}\text { Do you think that home-testing using bacterial or fungal } \\
\text { "point-of-care" testing technologies will: }\end{array}$ & \\
\hline & a) & Allow you to better monitor your patients' health? & $\begin{array}{l}\text { Yes } \\
\text { No } \\
\text { Don't know }\end{array}$ \\
\hline & b) & Allow patients to better monitor their health? & $\begin{array}{l}\text { Yes } \\
\text { No } \\
\text { Don't know }\end{array}$ \\
\hline
\end{tabular}


General practitioners (Continued)

\begin{tabular}{|c|c|c|c|}
\hline \multirow{3}{*}{ Q no } & \multirow{2}{*}{$\begin{array}{l}\text { Labels } \\
\text { c) }\end{array}$} & \multirow{3}{*}{$\begin{array}{l}\text { Question } \\
\text { Increase or decrease the number of visits patients make to } \\
\text { their general practitioner? }\end{array}$} & \multirow{2}{*}{$\begin{array}{l}\text { Options } \\
\text { Greatly increase }\end{array}$} \\
\hline & & & \\
\hline & & & Increase \\
\hline & & & Decrease \\
\hline & & & Greatly decrease \\
\hline & & & Have no effect \\
\hline & & & Don't know \\
\hline & d) & Impact on the doctor-patient relationship? & Yes (in a positive context) \\
\hline & & & Yes (in a negative context) \\
\hline & & & No \\
\hline & & & Don't know \\
\hline \multirow[t]{3}{*}{ II. } & & Do you think that there will be significant problems in & Yes \\
\hline & & interpretating the results of bacterial or fungal "point-of-care" & No \\
\hline & & diagnostic tests? & Don't know \\
\hline \multirow[t]{5}{*}{12.} & & In your opinion, would the introduction of bacterial or fungal & Definitely yes \\
\hline & & "point-of-care" diagnostic testing to the general practitioner's & Yes \\
\hline & & surgery, or within the patient's own home, affect the quality of & No \\
\hline & & patient care? & Definitely no \\
\hline & & & Don't know \\
\hline \multirow[t]{11}{*}{13.} & & What is your opinion on the following statements: & \\
\hline & a) & "Infectious disease home-testing kits are being developed that & Very favorable \\
\hline & & will allow people to test themselves at home without medical & Favorable \\
\hline & & supervision for the presence of infectious diseases?" & Unfavorable \\
\hline & & & Very unfavorable \\
\hline & & & No opinion \\
\hline & b) & "Test-kits are being developed that will allow people to be & Very favorable \\
\hline & & tested at their own general practitioner's surgery for the & Favorable \\
\hline & & presence of infectious diseases?" & Unfavorable \\
\hline & & & Very unfavorable \\
\hline & & & No opinion \\
\hline \multirow[t]{6}{*}{14.} & & Do you believe that the use of bacterial and fungal point-of- & Very positively \\
\hline & & care test(s) will positively or negatively affect how patients & Positively \\
\hline & & view your profession? & Negatively \\
\hline & & & Very negatively \\
\hline & & & Don't know \\
\hline & & & No effect \\
\hline \multirow[t]{13}{*}{15.} & & $\begin{array}{l}\text { Do you believe that the use of bacterial and fungal point-of- } \\
\text { care test(s) will positively or negatively affect: }\end{array}$ & \\
\hline & a) & Your health budget? & Very positively \\
\hline & & & Positively \\
\hline & & & Negatively \\
\hline & & & Very negatively \\
\hline & & & No change \\
\hline & & & Don't know \\
\hline & b) & The number of patient visits you receive? & Very positively \\
\hline & & & Positively \\
\hline & & & Negatively \\
\hline & & & Very negatively \\
\hline & & & No change \\
\hline & & & Don't know \\
\hline
\end{tabular}

Patient Preference and Adherence

\section{Publish your work in this journal}

Patient Preference and Adherence is an international, peer-reviewed, open access journal focusing on the growing importance of patient preference and adherence throughout the therapeutic continuum. Patient satisfaction, acceptability, quality of life, compliance, persistence and their role in developing new therapeutic modalities and compounds to

\section{Dovepress}

Submit your manuscript here: http://www.dovepress.com/patient-preference-and-adherence-journal

optimize clinical outcomes for existing disease states are major areas of interest. This journal has been accepted for indexing on PubMed Central. The manuscript management system is completely online and includes a very quick and fair peer-review system. Visit http://www.dovepress.com/ testimonials.php to read real quotes from published authors. 